\title{
Intensive Reading As a Study Habit and Students’ Academic Achievement in Economics in Selected Secondary Schools in Bayelsa State, Nigeria
}

\author{
Nnenna Ngozi Benwari ${ }^{1, *} \&$ Ebi- Bulami Bridget Nemine ${ }^{1}$ \\ ${ }^{1}$ Department of Teacher Education, Faculty of Education, Niger Delta University, Bayelsa State, Nigeria \\ *Corresponding author: Department of Teacher Education, Faculty of Education, Niger Delta University, Bayelsa \\ State, Nigeria. Tel: 234-803-707-8830 E-mail: nnennabenwari@mail.ndu.edu.ng
}

Received: July 26, 2014

Accepted: September 24, 2014

Online Published: October 6, 2014

doi:10.5430/jct.v3n2p94

URL: http://dx.doi.org/10.5430/jct.v3n2p94

\begin{abstract}
Learners acquire knowledge in various ways and in various degrees. This paper examined the effect of intensive reading, homework and assignment as study habits on academic achievement of students in selected secondary schools in Bayelsa State, Nigeria. The sample for this study was made up of 140 students randomly selected from the schools. Two research questions were raised and the Chi Square statistical tool was used to analyze the data. The result yielded the X2 values of 13.2 and 14.32 with a critical value 7.81. At 3 degree of freedom and 0.05 level of significant the result shows that intensive reading, homework and assignment as study habits are among the factors that affect academic achievement in Economics as a subject among secondary school students in Bayelsa State. The paper therefore recommended among other things that more emphasis should be laid on intensive reading as a study habit by students to improve on their academic achievement.
\end{abstract}

Keywords: intensive reading; study habit; academic achievement

\section{Introduction}

Study habits are strategies which a learner applies for acquiring knowledge, skills and ideas. Good study habits enhance academic performance and educational success. Study habits therefore, involve a series of activities and dispositions which a learner must acquire to enable him/her engage in academic studies. Students, sometimes perform far below the expected average. This may not be as a result of low ability level but often times as a result of poor study habits. The emphasis on study habits is based on theories that have been propounded on how to enhance academic performance among students through good study habits (Jemide 2001).

Economics, as one of the subjects studied at the senior secondary school level of the Nigerian educational system has often times been considered a very difficult subject. A student studying economics therefore needs to acquire and practice effective study habits in order to achieve academic success. In spite of other factors affecting performance, such as inadequate facilities, laziness, over-indulgence in television programmes and movies, social network (e.g. twitter, Facebook), lack of good library facilities at home and at school, poor lighting system, emergence of secret cults, and general indiscipline, educational success requires the acquisition of effective and good study habits, dedicated pursuit of learning and willingness to accept corrections (Agina-Obu 2001). Some of such study habits include intensive reading, note taking, group-study, attending to class activities, partaking in home work and assignment. However, this paper focuses on intensive reading.

\subsection{The Problem}

The problem of poor academic achievement in various school subjects and Economics in particular has been an issue of great interest among educationists. This poor performance is seen in both internal and external examinations such as the Senior Secondary School Certificate (SSCE). Many factors are believed to be responsible for students' academic achievement in secondary schools and one of these are poor study habits. Researchers over the years have shown that there are different ways in which a student can study. It is further revealed that these habits produce different or various results. This variation in students' academic performance has necessitated this study. The 
purpose of this study therefore, is to find out the extent to which intensive reading positively influences academic achievement among students of Economics in secondary schools in Bayelsa State, Nigeria.

\subsection{Research Questions}

The study was guided by the following Research Questions:

1. How does intensive reading affect the academic achievement of students of Economics in Bayelsa State?

2. To what extent does carrying out homework and assignments affect the academic achievement of students?

\section{Concept of Academic Achievement}

The need for academic achievement has over the years been a propelling force for scholars in the field of study. The problem is not only defining the concept but also trying to advance practical ways of improving academic achievement. Despite the intriguing scenario, some intellectuals have distinguished themselves by making reasonable headway into unraveling the concept of academic achievement as performance in school or college in a standardized service of educational test. Aiken (2000) has defined achievement as the degree of ability already attained while Anastas (2000) asserted that it is the aspect of measuring the effects of negatively standardized sets of experience. What this definition means is that achievement is a past performance. Interestingly, some scholars view achievement as relating to the classroom alone. Thus the proponents of this view believe that achievement is measured based on the student's performance in a test or examination in which the outcome is the achievement.

Academic achievement is the level of performance that is exhibited by an individual. In other words, it is the degree of success attained at the end of an academic exercise which can be conceived to mean the extent one is able to accomplish after learning has taken place. Academic achievement can be known as the level of efficiency and knowledge demonstrated by an individual after learning has occurred (Irogbo 2002).

In his contribution, Farnati (2000) proposed that thoroughness, re-learning and reading materials which can be used in answering the questions that arise from the reading would contribute good study habits which enhance academic achievement. While reviewing the materials, the reader tries to examine what he/she has read and can bring them to memory. The reader also finds the relationship between major points and supporting elements. The foregoing habits can be summed up as strategies that learners can adopt in the process of acquiring knowledge, ideas, skills and experience. Asagwara (2001), has argued that bad reading habits make the process of knowledge acquisition rigorous and painstaking whereas good reading habit make the learner to acquire knowledge with ease, conserving the learners effort, energy, time and the likes. He mentioned that there are good and poor study habits with no controversy at all. The issue is what underscores habits' formation. Premised on this Denga (2001), opined that habits are formed by motives and needs, and that the society frowns at unfavorable behaviour. Education becomes the machine through which individual character traits are fine tuned. Hence, desirable behaviour that can enhance harmony is appreciated.

Denga, (2002), further described man as a creator of habits. He states that man has the ability to create habits that will enable him achieve pressing needs hence; he can form habits of study, emotional control, habitual attitudes and habit of consumption. He also noted that man has been described man as a bundle of walking habits. Study habits are important concepts. In education, teachers are concerned with the task of identifying and inculcating or promoting good study habits in their students. Students need good study habits for higher academic achievement. But such habits do not come by chance.

In line with this, Koko (2001) stated that teachers need to identify the best ways of motivating students so that they can develop interest in learning. Habits are formed by extensive trail and experiences. The implication is that acquiring good study habits comes by means of regular repeated processes (Asagwara 2000).

Another distinguished scholar, Bakare (2000), postulated some dimensions of good study habits to include test-anxiety, task accomplishment, reading and note-taking, private/group study, home work and assignment, makeup for missed-notes, teachers'/students' interaction, reading materials, family/school responsibilities, teachers consultation, maximum attention in written work. He said the learner must be motivated for these variables to elicit expected outcomes. Academic achievement here is not only dependent on how best the learner is motivated, but on proper application of these variables (Park, 2001).

Nevertheless, it is up to the teacher to harmonize problems associated with these variables to achieve results. Obomany (2000) has revealed that students have their individual peculiarities in study habits and the short 
sightedness in most cases lead to disappointing performance in test and examinations. The implications therefore are that since study habits employed were not effective academic performance must be affected.

\subsection{Factors That Enhance Academic Achievement}

There are various factors that enhance academic achievement and these include intensive reading, home work and assignment, class work activity, note taking and group study.

\subsection{Intensive Reading}

To start with, reading is said to be the act of understanding the meaning of a written or printed word (or symbol) or the act of obtaining knowledge or information through books, magazines, journals etc. One must read with a purpose which is, to understand. A student who forms the habit of reading performs better than those who do not read but rather prefer to spend their time on non profitable things that cannot promote their educational attainment/performances. It has been noted that learners achieve more when they become more proficient in reading and reasoning. In addition, the use of proper scheduling, time allocation and sleep timing can also enhance effective reading. Furthermore, Asagwara (2000), opined that study attitude can be summed up to mean strategies that a learner adopts in the process of acquiring knowledge, ideas, skills and experience.

Before one begins to think about the process of studying, one must develop a schedule. If one does not have a schedule or plan of studying, such person will not have a way of allocating valuable time when other activities come up unexpectedly. A good and well thought-out schedule can be a life-saver. Consequently, lack of strict adherence to the issue of time schedule may lead young children/students to devoting inadequate time to study and thereby resulting to failure. Students should use a good schedule, and maximize their time in doing essential academic work. This is the ability of the student to plan and apportion limited available study time to different subjects of study. An adequate time allocation and distribution is very essential for an effective and efficient study for success.

Hence students who apportion enough time to their studies will hopefully attain higher academically than students who play away their useful time. Thus no activity should be done in excess but as appropriate. Excess sleep for instance is usually condemned but students need to get enough sleep, at least eight or nine hours of sleep each night, in order for them to be able to concentrate when reading. Students who carry out their academic work according to schedule and at the appropriate time also have enough sleep, while students who do not sleep at the right time end up waking up late which can affect the student's performance academically.

\subsection{Home Work and Assignment}

This is the way students attend to their home work and school assignment. It is concerned with the ability of students to take their home work and assignment seriously and submit promptly. Carrying out homework and school assignment give the students a degree of confidence on answering examination questions. Furthermore, Asagwara (2001) confirms that acquiring good study attitude comes by means of a regular repeated process. Students who develop the habit of doing their home work and assignment will hopefully perform better than those who shy away from doing their home work and assignment.

\section{Design of the Study}

This study adopted a survey design. According to Hassan (1995), the survey method involves direct contact with personalities, qualities or attributes, which are relevant to a specific investigation. Therefore, the survey method was used in investigating study habits and academic achievement among selected Secondary School students in Bayelsa State.

\subsection{Population of the Study}

The population for this study comprises of students studying Economics in Senior Secondary Schools in Yenagoa metropolis of Bayelsa State, Nigeria.

\subsection{Sample and Sampling Technique}

A sample of One hunderd and forty (140) senior secondary school students (S.S.S) were used in the study. A disproportionate simple random sampling technique was used to obtain the 140 students from the various schools. 


\subsection{Instrument}

The instrument that was used for data collection is a 20 item self structured questionnaire scored on a four - point Likert scale format ranging from strongly agree (SA) 4 points, Agree (A) 3 points, Disagree (D) 2 points and Strongly Disagree (SD)1 point.

3.4 Administration of the Instrument

The questionnaire was administered directly to the respondents in the schools.

\subsection{Method of Data Analysis}

The data was analyzed with the use of frequency tables, percentages and Chi Square inferential statistics of the questionnaires at 0.05 level of significance and 3 degree of freedom.

\section{Results}

The results obtained from the study are presented below.

Table 1. Students' Response on Intensive Reading and Academic Achievement in Economics

\begin{tabular}{llllll}
\hline & Strongly Agree & Agree & Disagree & $\begin{array}{l}\text { Strongly } \\
\text { Disagree }\end{array}$ & Total \\
\hline f0 & 40 & 50 & 30 & 20 & 140 \\
f0..f & 35.0 & 35.0 & 35.0 & 35.0 & 35.0 \\
f0-fe & 5 & 15 & -5 & -15 & \\
(f0-fe) 2 & 25 & 225 & 25 & 225 & \\
(f0-fe)/fe & 0.14 & 6.42 & 0.14 & 6.42 & 13.12 \\
$\%$ & 28.57 & 35.71 & 21.42 & 14.28 & 100 \\
\hline
\end{tabular}

\section{Observed Chi-Square Value (X2)=13.12}

\section{Critical Value $=7.81$}

\section{Degree of Freedom $(\mathbf{d l})=3$}

\section{Level of significance $=\mathbf{0 . 0 5}$}

The table above shows the result of the Chi square (X2) analysis of intensive reading as a study habit for academic achievement of Economics among Secondary Students in Bayelsa State. The table indicates that 40 (28.57\%) strongly Agree, 50(35.71\%) Agree, 30 (21.42\%) Disagree, 20 (14.28\%) Strongly Disagree

Further the table shows X2 value 13.12 and a critical value of 7.81 at 3 degrees of freedom at 0.05 level of significance. The table value of 13.12 is greater than the critical of 7.81. The table indicates that intensive reading as a study habit is among the factors that affect the academic achievement in Economics among Secondary School Students.

Table 2. Students' Response on Home Work/Assignment Study Habits and Academic Achievement in Economics

\begin{tabular}{llllll}
\hline & Strongly Agree & Agree & Disagree & $\begin{array}{l}\text { Strongly } \\
\text { Disagree }\end{array}$ & Total \\
\hline f0 & 45 & 46 & 30 & 19 & 140 \\
f0..f & 35.0 & 35.0 & 35.0 & 35.0 & 35.0 \\
f0-fe & 5 & 15 & -5 & -15 & \\
(f0-fe) 2 & 25 & 225 & 25 & 225 & \\
(f0-fe)/fe & 0.14 & 6.42 & 0.14 & 6.42 & 14.32 \\
$\%$ & 32.14 & 32.85 & 21.42 & 13.57 & 100 \\
\hline
\end{tabular}

\section{Observed Chi-Square Value (X2)=14.32}

\section{Critical Value $=7.81$}

Degree of Freedom $(\mathrm{dl})=3$

\section{Level of significance $=0.05$}

The results above shows the Chi square analysis of home work and assignment as a study habit for academic achievement in Economics among Secondary Students in Bayelsa State. The table indicates that 45(32.14\%) Strongly Agree, 46(32.85\%) Agree, 30(21.42\%) Disagree, 19(13.57\%) Strongly Disagree. Further the table shows 
$\mathrm{X} 2$ value 14.32 and a critical value of 7.81 with 3 as degree of freedom at 0.05 level of significant. The table value of 14.32 is greater than the critical of 7.81. Thus we conclude that good habit of attending to home work and school assignments affect the academic achievement of secondary school students in Economics.

\section{Discussion of Findings}

The purpose of this study was to ascertain how study habits such as intensive reading, proper attendance to home work and school assignments affect the academic achievement of Economics students in senior secondary schools in Bayelsa State, Nigeria. The result on first table (table 1) which provides the answer to research question one shows that intensive reading as a study habit positively affects the academic achievement of students in Economics. This confirms the opinion of Tobin and Copic (1982) who found out that learners achieve more when they become more proficient in reading and reasoning. Also, they opined that the use of schedules, time allocation and sleeping schedules can also enhance effective intensive reading. Intensive reading was also noted to make students to jot down important points they come across while reading which enhances their ability to recall this points when needed.

The result presented on the second table (table 2) above also shows that carrying out school homework and assignments positively affect the academic achievement of secondary school students in Economics in Bayelsa State, Nigeria. This is in conformity with the findings of Robinson and Corey (2000) that regular class attendance, doing homework/assignment are some of the effective study habits for improved academic achievement. These study habits ensure that students read their class notes as often as possible.

The study further revealed that a good environment, studying with others, studying and discussing with friends and classmates make learning easy. This also in agreement with the findings of Koko, (1999), that poor academic achievement or failure is a consequence of poor study habits. Time is also said to be very important for students in education. This study has revealed that a good use of time improves academic achievement. The technique used for effective studying should be done with every amount of thoroughness and concentration (Memory 2001). Asagwara (2000) has also confirmed that acquiring good study habits comes by means of a regular repeated process and that the study attitude and strategies that a learner adopts in the process of acquiring knowledge, skills and experience enhance their academic achievement.

\section{Conclusion}

This study was carried out to ascertain the effect of study habits such as intensive reading, carrying out home work and school assignments on the academic achievement of secondary school students in Economics in Bayelsa State of Nigeria. The findings of the study shows that intensive reading, home work and school assignments are study habits that positively affect academic achievement of the students. Thus poor study habits invariably lead to poor performance among the students. The paper therefore recommends that the teachers and all who are involved in the educational process should not leave students to their own devices but provide them adequate knowledge of reading habits. Students should also be provided an enabling environment which will encourage good study habits and thus enhance academic achievement.

\section{References}

Agina-Obu, T.N. (2001). 'Students Attitudes and Perception of Teachers' Teaching Methods and Achievment in Biology. Journal of Psychology and Counseling, 1(3), 91-97.

Aiken, T. (2000). Meaningful study techniques and students at school. Journal of Psychology and Counselling, 1(3).

Akinboye, H. I. (2000). A Study on studnets achievement and ability. Nigeria Educational Research Journal, 1, 66-73.

Anastas, W.E (2000). The effects of study habits on academic performance. Port Harcourt: Dolan Publishers.

Asagwara, C. G. (2000). Study habits dimensions and effective application in schools. Calabar: Sea Fruit Company.

Asagwara, C.G. (2001). The school counsellors' roles and students academic success. Calabar: Sea Fruit Company.

Asuru, U.A. (1999). Examination malpractice: Trend, cases, effects and solution. Port Harcourt: S.I.T. Publishers.

Bakare, C.G.M. (2000). Study habits inventory: Psychological educational research project manual. Ibadan. 
Denga, A.M. (2001). The effect of study habits on academic performance of Business Education students in tertiary institutions of Rivers State. Unpublished bachelors degree project, University of Port Harcourt, Rivers State.

Hassan, R. (2002). The impact of family background factors on academic achievement: A review of findings. Journal of Technical Teacher Education. FCOE Omoku.

Ihiegbulern, G.O (2001). The Relationship between Educational Achievement and School Size. Unpublished Seminar Paper, Faculty of Education, University of Nigeria, Nsukka.

Irogbo, I. (2002). Reading to Remember: A Guide of Effective Reading. Enugu: Longway Publishers.

Jemide, W.I. (2001). Attitudes to student educational advanacement. Ibadan: Dolan Publishers.

Koko, M.N. (1999). Teaching Business (Methods and Procedures). Owerri: Best Hands Publishers.

Memory, R.W. (2001). Essentials of Learning. New York: Macmillan Publishers.

Obomany, P.A. (2000). Factors that enhance Effective Habits in Schools. Unpublished seminar paper. University of Science and Technology, Port Harcourt.

Onyejiaku, E.O. (2002). Technique for Effective Study. Calabar: Wusen Press.

Pages \& Thomas, W. (2001). Self- concept study: Behaviour and cognitive performance of 6” grade boys on relation of their teaching of intellectual achievement responsibility. India Journal of Behaviour.

Park, W.G. (2001). Causes of poor academic performance among secondary students. Unpublished Seminar Paper. Faculty of Education, Niger Delta University, Wilberforce Island, Nigeria.

Robinson D., \& Corey G. (2000). Techniques to Effective Reading in Psychology and Education. New York: Wiley and Sons.

Wittmare E.D. (2000). Problems Associated with the Academic Performance of Business Education Student in Nigeria Tertiary Institutions: A survey of River State College of Education. Unpublished Bachelor's Degree Thesis. Rivers State College of Education, Port Harcourt. 